\title{
PHYTOCHEMICAL STUDIES AND GC-MS ANALYSIS OF SPERMADICTYON SUAVEOLENS ROXB
}

\author{
RUTHIRAN PAPITHA ${ }^{1}$, LOKESH RAVI², CHINNADURAI IMMANUEL SELVARAJ ${ }^{*}$,
}

1Department of Biotechnology, School of Biosciences and Technology, Vellore Institute of Technology University, Vellore, India, ${ }^{2}$ Department of Biomedical Science, School of Biosciences and Technology, Vellore Institute of Technology University, Vellore, India Email: immanuelselvaraj@vit.ac.in

Received: 07 Nov 2016 Revised and Accepted: 17 Jan 2017

\section{ABSTRACT}

Objective: The present study was performed to identify the phytochemical constituents of leaves and flowers of a plant Spermadictyon suaveolens extracted with four different solvents.

Methods: Dried and powdered samples were subjected to soxhlation based on the polarity of the solvents. The extracts were scanned using Ultra Violet-visible (UV-Vis) spectrophotometry with the wavelength ranging from $200-800 \mathrm{~nm}$ by comparing the absorption spectrum with the spectra of known compounds, Fourier Transform Infrared (FT-IR) spectrometry was used to find out the functional groups of the compounds and GC-MS system consisting of a Perkin Elmer Technologies Model Clarus $680 \mathrm{GC}$ equipped with Clarus 600 (EI) was used to identify the metabolites by matching their recorded mass spectra with the standard mass spectra from National Institute of Standards and Technology (NIST05. LIB) libraries provided by the software of the GCMS system (Turbo Mass version 5.4.2).

Results: The phytochemical tests indicated the presence of carbohydrates, alkaloids, flavonoids, phenols, tannins, saponins and terpenoids from the chloroform extract of leaves and flowers. UV-visible spectrophotometer results indicated a wavelength range between $230-660 \mathrm{~nm}$ for the flower and leaf extracts for major peaks. FT-IR analysis indicated major functional groups such as aromatic, primary, secondary and aliphatic amines, alkanes, carboxylic acids and amides. GC-MS analysis results revealed major bioactive compounds in the crude extracts.

Conclusion: Presence of secondary metabolites has been identified from the phytochemical studies. Many phyto-compounds have been identified from the leaves and flowers of using GC-MS analysis. Hence, this medicinal plant may be used as a source for treating many diseases.

Keywords: Medicinal plant, Phytochemical screening, UV-visible spectrophotometry, FTIR, GC-MS

(C) 2016 The Authors. Published by Innovare Academic Sciences Pvt Ltd. This is an open access article under the CC BY license (http://creativecommons.org/licenses/by/4. 0/] DOI: http://dx.doi.org/10.22159/ijpps.2017v9i3.16059

\section{INTRODUCTION}

Medicinal plants besides being used as a source of therapeutic agents also contain an extensive range of chemical constituents which could be developed as drugs with few selective compounds. They are the pools of useful chemical compounds which may serve as pointer and evidence for modern drug design [1]. Naturally, present phytochemicals in leaves, fruits, seeds, barks and roots of medicinal plants have a protective and resistant mechanism for various diseases. Phytochemicals contain both primary and secondary compounds. Chlorophyll, proteins and common sugars are considered as primary compounds and terpenoids, alkaloids, flavonoids, saponins and phenolic compounds are appraised as secondary compounds [2]. Terpenoids reveals significant pharmacological action against inflammation, cancer, malaria, viral and bacterial infections, [3]. Alkaloids are considered as anaesthetic agents, inhibitors of microorganisms, antihypertensive effects and possess antimalarial activities which are mainly found in medicinal plants [4].

Spermadictyon suaveolens belongs to the family of Rubiaceae. It is commonly known as "Forest Champa" 'Van-champa', 'Gidesa', 'Jitsaya'. It is branched shrub, 1-2m tall, branches divaricate. Leaves are dark green in colour opposite, elliptic, lanceolate, narrowed at base. The stems are gray in colour, circular in shape. Flowers are small, white, and fragrant. Seeds are few, triquetrous, surrounded by a loose lace-like covering. Capsules 5 valved [5]. It is dispersed commonly in Maharashtra. It shows the wide distribution in tropical dry/moist deciduous forests. It is also distributed in the Himalayas. China cultivates $S$. suaveolens for its fragrant flowers. Roots are useful for production of oil which can be used to treat wounds and found to have wound healing property. The roots are also used in the treatment of diabetes, rheumatoid arthritis and bloody dysentery in veterinary medicine $[6,7]$. The traditional healers of the Maharashtra use roots and stem for curing the diseases associated to the bone, wound healing, diabetes, Herpes, etc. There are 30 bioactive phyto-compounds identified in the extracts of $S$. suaveolens reported from the root of this plant. The stem powder of this plant is used by herbal medicinal practitioners for control of viral infections like herpes as well as to diabetes [8]. Several researchers are paying attention towards this plant and its drug in recent days due to its broad activity. Insufficient pharmacognostic assessment of this astonishing plant has been done so far, The rationale and the key objective of the present study is to identify the phytochemical constituents present in leaves and flowers of the plant Spermadictyon suaveolens extracted with four different solvents based on the polarity.

\section{MATERIALS AND METHODS}

Medicinal plants were collected from the Foundation for Revitalization of Local Health Traditions (FRLHT), Jarakbande Kaval, (13 ${ }^{\circ} 6^{\prime}$ 30.6936" N latitude and $77^{\circ}$ 32' 10.1256" E longtitude) Bengaluru, Karnataka, India. The plant materials were identified based on the morphology and taxonomy on the field by plant taxonomist N. M. Ganesh Babu PhD, Bengaluru, Karnataka, India. Plant materials were cleaned and shade dried at room temperature $\left(37^{\circ} \mathrm{C}\right)$ for ten days. The dried plant materials were powdered and the sample was subjected to sequential soxhlation extraction using petroleum ether, chloroform, ethyl acetate and methanol (Merck India Limited, Bangalore). The extracts were filtered in $1 \mu \mathrm{m}$ pore size Whatman filter paper and purely refined extracts were used in this study. The plant extracts were tested for the presence and absence of secondary metabolites using phytochemical analysis by standard methods $[9,10]$.

\section{a. UV-visible spectrophotometry}

The absorbance and wavelength of the peaks were determined for the methanolic and chloroform plant extracts by a wavelength scan between 200 and $800 \mathrm{~nm}$ [11]. The UV-visible spectra were recorded on a (Shimadzu UVd-1800 PC, Japan) UV-Vis spectrophotometer. 


\section{b. FT-IR analysis}

FTIR analysis was performed using Magna 750 FTIR spectrometer equipped with a DTGS (Deuterated Triglycine Sulfate) detector, NiChrome source and $\mathrm{KBr}$ beam splitter. The spectrum of the solvent extracted plant samples were observed at the range of 4000-500 $\mathrm{cm}^{-1}$ with a resolution of $4 \mathrm{~cm}^{-1}$. The spectrum details were collected and processed using Omnic software version 7.3

\section{c. Gas column-mass spectrophotometry analysis}

Five milligrams of the solvent extracted sample was weighed, powdered and transferred to a sterile clean test tube and dissolved with the desired solvent. The sample solution was filtered using 0.2 $\mu \mathrm{m}$ nylon membrane and the filtered sample solution was injected into the column for running GC-MS. The analysis was carried out on a Perkin-Elmer workstation, with model Clarus $600 \mathrm{GC}$ coupled to a mass spectrometer (Perkin Elmer Technologies, Inc., Wilmington, DE). Elite-5MS ( $30 \mathrm{~m} \times 0.25 \mathrm{~mm}$ width film depth of $250 \mu \mathrm{m}$ capillary tube was used under the following condition. The instrument has an oven with an initial temperature of $55{ }^{\circ} \mathrm{C}$ for $3 \mathrm{~min}$ and a ramp program which elevates from $6^{\circ} \mathrm{C} / \mathrm{min}$ up to $310^{\circ} \mathrm{C}$, further $3 \mathrm{~min}$ isothermal hold. Helium ( $\mathrm{He}$ ) carrier gas was used, with flow rate split ratios of 10:1. Two $\mu \mathrm{l}$ volumes of samples were injected and temperature of the injector was maintained to $250^{\circ} \mathrm{C}$. An individual component was recognised with typical mass spectra from National Institute of Standards and Technology (NIST-LIB 0.5) libraries which is inbuilt by the software of the GCMS system (Wiley GC-MS-2007) and literature data. The individual phytochemicals present in the crude extract were separated by the gas chromatography column.

An individual compound separated by GC enters the Mass Spectrum (MS) and gets ionized. The MS ionizing spectrum was recorded and compared to the MS spectrum of known compounds in the NIST library. Each compound was compared with a percentage score of reverse and forward spectrum. The MS spectrum displays the molecular weight of individual molecules accurately.

\section{RESULTS AND DISCUSSION}

The leaves and flowers were subjected for phytochemical analysis to identify the presence and absence of carbohydrates, alkaloids, flavonoids, phenols, tannins, saponins, and terpenoids in Spermadictyon suaveolens (table 1). Almost all the phyto-compounds were present in the leaves and flowers of the plant based on the analysis with four different extracts.

Table 1: Phytochemical profiles of four different solvent extracts of Spermadictyon suaveolens flowers and leaves

\begin{tabular}{|c|c|c|c|c|c|c|c|c|c|}
\hline \multirow[t]{2}{*}{ S. No. } & \multirow{2}{*}{$\begin{array}{l}\text { Solvents } \\
\text { Phytochemical tests }\end{array}$} & \multicolumn{2}{|c|}{ Petroleum ether } & \multicolumn{2}{|c|}{ Chloroform } & \multicolumn{2}{|c|}{ Ethyl acetate } & \multicolumn{2}{|c|}{ Methanol } \\
\hline & & Flowers & Leaves & Flowers & Leaves & Flowers & Leaves & Flowers & Leaves \\
\hline 1 & Carbohydrates & -- & -- & ++ & ++ & -- & ++ & ++ & ++ \\
\hline 2 & Alkaloids & ++ & -- & ++ & -- & ++ & ++ & ++ & ++ \\
\hline 3 & Flavonoids & ++ & ++ & ++ & ++ & -- & ++ & -- & -- \\
\hline 4 & Phenolics & ++ & ++ & ++ & ++ & ++ & ++ & -- & ++ \\
\hline 5 & Tannins & ++ & ++ & ++ & ++ & ++ & ++ & -- & -- \\
\hline 6 & Saponins & ++ & -- & ++ & ++ & -- & -- & ++ & -- \\
\hline 7 & Terpenoids & -- & ++ & ++ & ++ & ++ & ++ & ++ & ++ \\
\hline
\end{tabular}

+Indicates; presence;-indicates; absence

UV-visible spectrophotometer readings of $S$. suaveolens flower (chloroform) extract showed four peaks. The UV spectrum peaks are at $270 \mathrm{~nm}, 320 \mathrm{~nm}, 430 \mathrm{~nm}$ and $660 \mathrm{~nm}$ with the absorption values of $0.37,0.27,0.13$ and 0.05 considered individually. Chloroform extract of $S$. suaveolens leaves showed two peaks at $230 \mathrm{~nm}$ and 370 $\mathrm{nm}$ with the absorption of 3.5 and 3.0. Methanolic leaf extract of has two spectral peaks at $240 \mathrm{~nm}$ and $330 \mathrm{~nm}$ with the absorption of 1.7 and 0.7 respectively. The UV-Vis spectrum of above-mentioned extracts was illustrated in fig. 1.
FTIR was used to analyze and identify functional groups of active compounds based on major peak values [12]. Results were compared using the infrared chart. Flower extract has aromatic, primary, secondary and aliphatic amines and amides were found (fig. 2). Methanolic and chloroform leaf extracts showed the aromatic functional group as a major peak followed by primary and secondary amines, amides, and alkanes except for carboxylic acids which were found only in methanolic leaf extract (fig. 3 and 4). The overall details of the FTIR analysis were given in table 2.
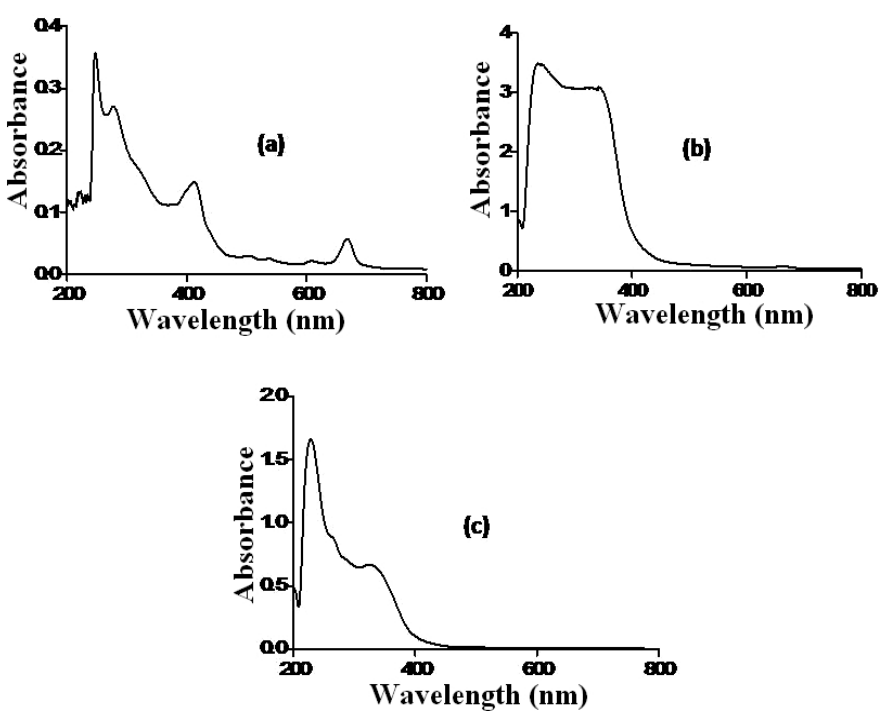

Fig. 1: UV-VIS spectrum of S. suaveolens. (a) Chloroform extract of S. suaveolens flowers; (b) chloroform extract of S. suaveolens flowers; (c) Methanolic extract of $S$. suaveolens leaves 


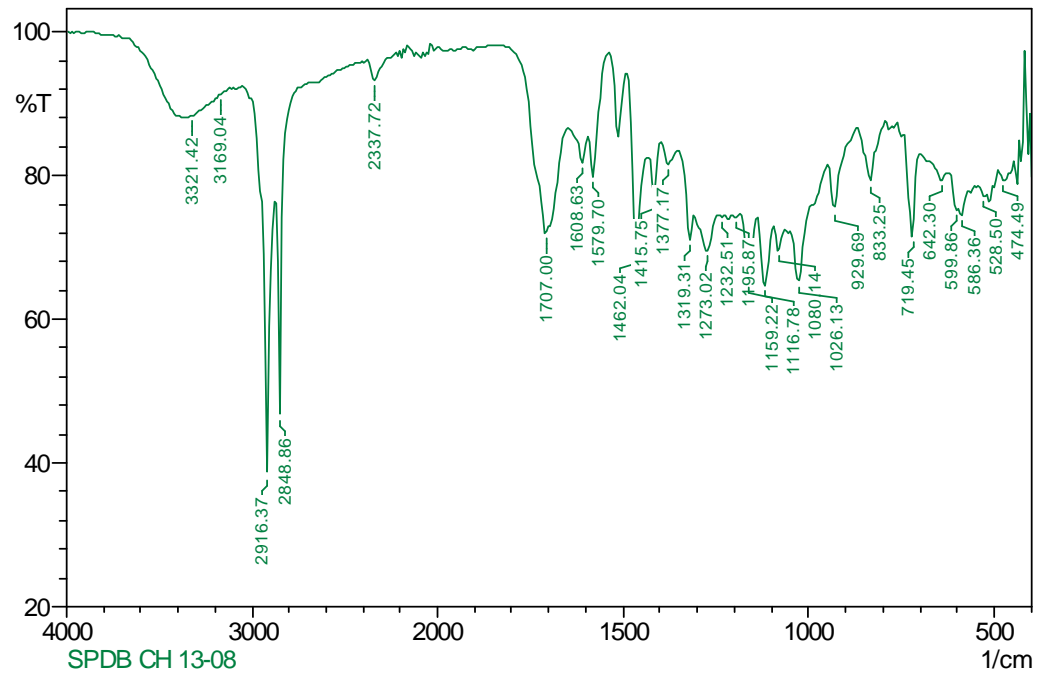

Fig. 2: FT-IR spectrum of chloroform extract $S$. suaveolens flower

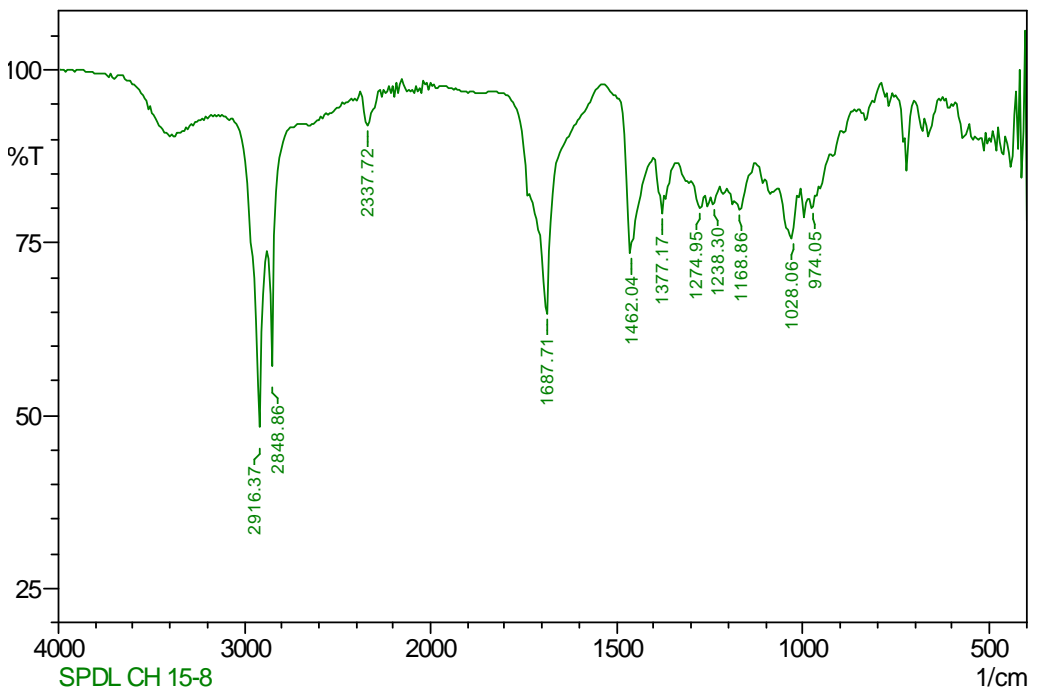

Fig. 3: FT-IR spectrum of chloroform extract $S$. suaveolens leaf

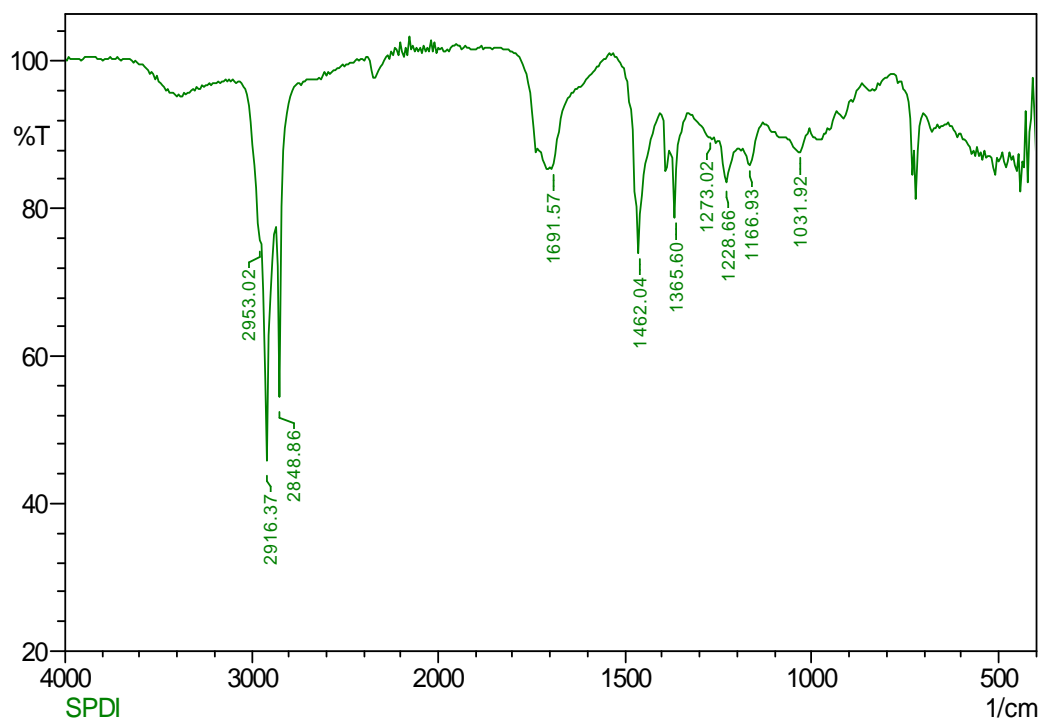

Fig. 4: FT-IR spectrum of methanolic extract $S$. suaveolens leaf 
Table 2: Functional group analysis of FT-IR spectrum for S. suaveolens leaf and flower extract

\begin{tabular}{|c|c|c|c|}
\hline Plant part used & Peak values & Structural unit & Functional groups \\
\hline \multirow{4}{*}{ Flower extract (chloroform) } & 2916 & $\mathrm{C}-\mathrm{H}$ & Aromatic \\
\hline & 2848 & $\mathrm{~N}-\mathrm{H}$ & $1^{\circ}, 2^{\circ}$ amines, amides \\
\hline & 1707 & $\mathrm{C}=\mathrm{O}$ & $\alpha, \beta$-unsaturated aldehydes, ketones \\
\hline & 1026 & $\mathrm{C}-\mathrm{N}$ & Aliphatic amines \\
\hline \multirow[t]{4}{*}{ Leaf extract (chloroform) } & 2916 & $\mathrm{C}-\mathrm{H}$ & Aromatic \\
\hline & 2848 & $\mathrm{~N}-\mathrm{H}$ & $1^{\circ}, 2^{\circ}$ amines, amides \\
\hline & 1687 & $\mathrm{C}=\mathrm{O}$ & Carboxylic acids \\
\hline & 1462 & $\mathrm{C}-\mathrm{H}$ & Alkanes \\
\hline \multirow{3}{*}{ Leaf extract (methanol) } & 2916 & $\mathrm{C}-\mathrm{H}$ & Aromatics \\
\hline & 2848 & $\mathrm{~N}-\mathrm{H}$ & $1^{\circ}, 2^{\circ}$ amines, amides \\
\hline & 1365 & $\mathrm{C}-\mathrm{H}$ & Alkanes \\
\hline
\end{tabular}

The study on the active principles of Spermadictyon suaveolens flowers by GC-MS analysis exhibited the presence of eight major peaks in the methanolic extract (fig. 5), corresponding to compounds adamantine methylamine, alpha-methyl-with a retention time of (16.70), has antiviral activity [13]. 3,7,11,15-tetramethyl-2-hexadecen-1-ol (17.07) showed analgesic, anti-inflammatory and antipyretic activities [14]. 1octadecyne (17.51) antibacterial [15]. Phytol (19.75) antiinflammatory [16] Phosphine, triphenyl (20.03) was reported to have In vivo and in-vitro inhibition of rat neurotoxic esterase [17]. 1,6;3,4dianhydro-2-deoxy-. Beta-d-lyxo-hexo-pyranose (21.66) bioactivity of a natural compound isolated from cyanobacteria[18]. Cyclotrisiloxane, hexamethyl-(30.00) showed antibacterial activity [19]. The details were given in table 3 .

Spermadictyon suaveolens leaf extracted with chloroform showed ten major peaks in the GC-MS spectrum (fig. 6). Phenol, 2, 4-bis (1, 1dimethylethyl) (13.41) was reported to possess antifungal, antimicrobial, antimalarial, UV stabilizer and an antioxidant for hydrocarbon-based products [20]. The compound 3,7,11,15tetramethyl-2-hexadecen-1-ol (17.08) was reported to have antimicrobial, anticancer, anti-inflammatory, anti-diuretic [21], Pentatriacontene (20.05) an herbistat [22], Eicosane, 9-octyl-(22.74) with anticancer activity [23], Octadecane, 3-ethyl-5-(2-ethylbutyl (25.97) was reported to possess In vitro antifungal activity [24]. The details were given in table 4 .

GC-MS spectrum of the methanolic extract of $S$. suaveolens leaves indicated eight major peaks (fig. 7). 4-acetoxy-3-methoxystyrene (11.92) was reported in DSC studies on hydrogen bonding and related derivatives [25], Hexadecanoic acid, ethyl ester (18.71) showed antibacterial activity [26], 1,2-benzenedicarboxylic acid, mono (2ethylhexyl) ester (23.39) indicated antimicrobial activity [27], Tetratetracontane (27.60) antioxidant [28], Beta-sistosterol (30.75) with antimicrobial activity [29]. The details were given in table 5 .

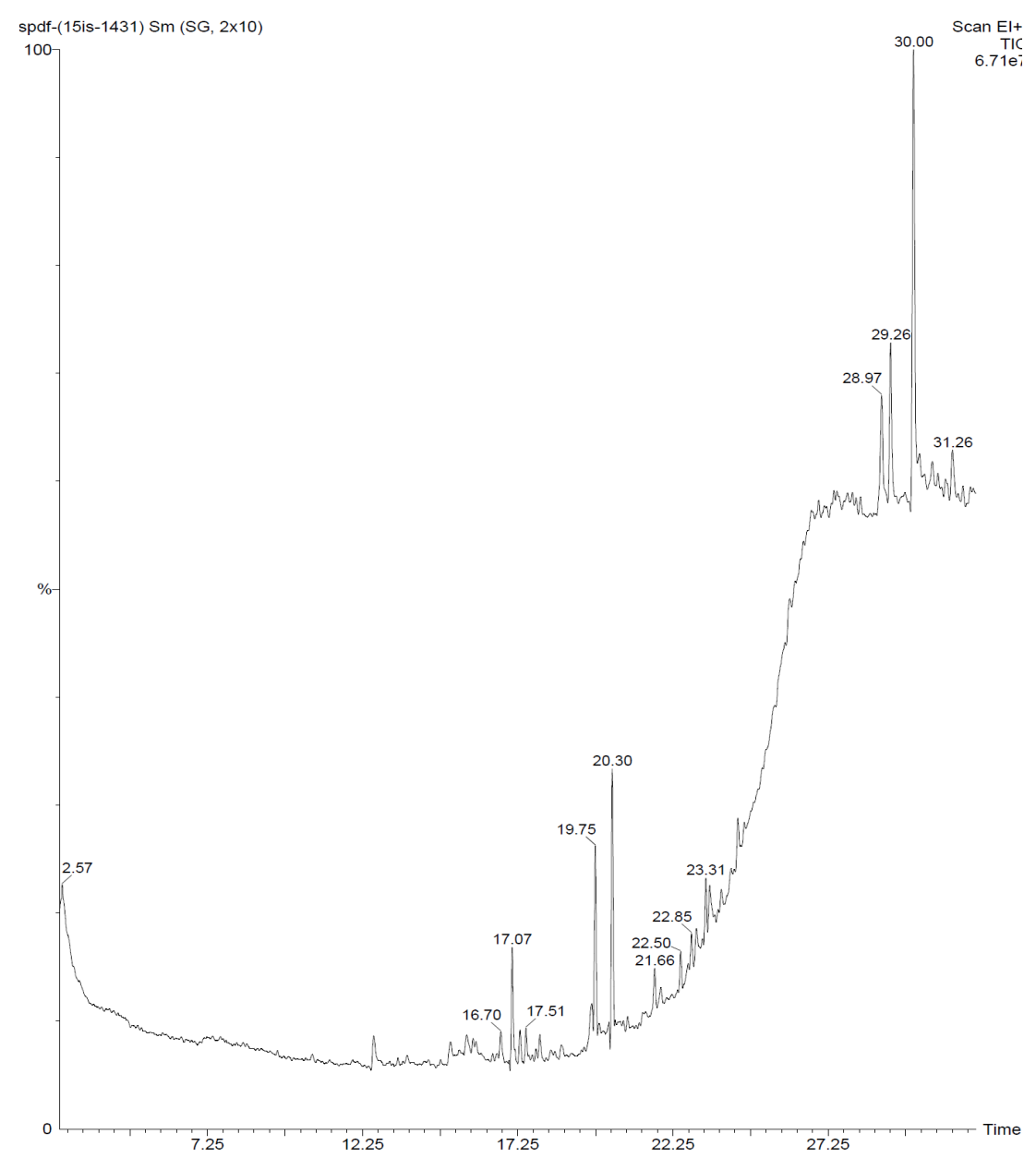

Fig. 5: GC-MS chromatogram of chloroform extract of S. suaveolens flower 


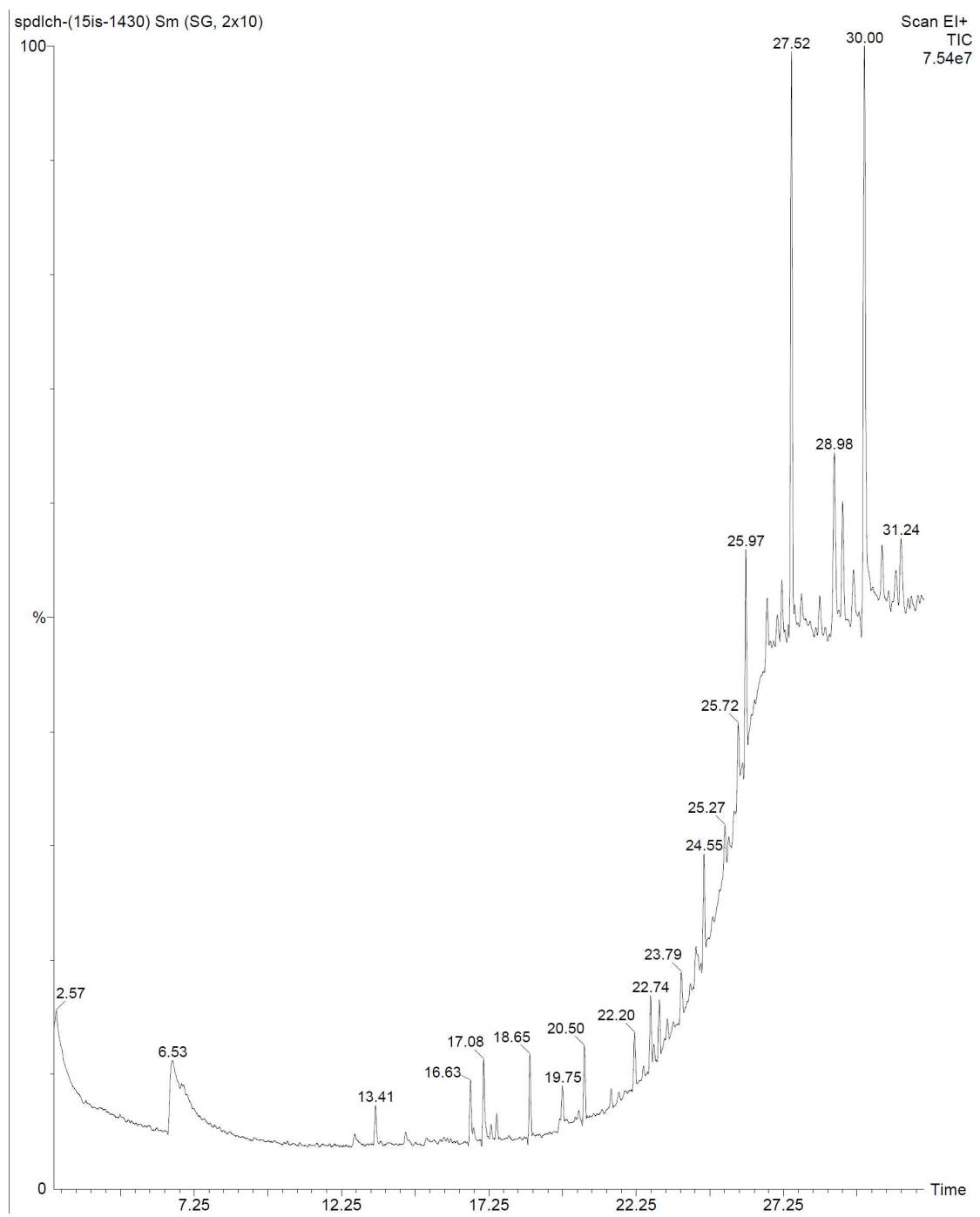

Fig. 6: GC-MS chromatogram of chloroform leaf extract of $S$. suaveolens leaf

Table 3: Chemical composition of Spermadictyon suaveolens flowers (chloroform extract)

\begin{tabular}{llll}
\hline S. No. & RT & IUPAC name & Chemical formula \\
\hline 1. & 16.70 & Adamantine Methylamine, Alpha.-Methyl- & $\mathrm{C}_{12} \mathrm{H}_{21} \mathrm{~N}$ \\
2 & 17.07 & $3,7,11,15-T e t r a m e t h y l-2-H e x a d e c e n-1-o l$ & $\mathrm{C}_{20} \mathrm{H}_{40} \mathrm{O}$ \\
3 & 17.51 & 1-Octadecyne & $\mathrm{C}_{18} \mathrm{H}_{34}$ \\
4 & 19.75 & Phytol & $\mathrm{C}_{20} \mathrm{H}_{40} \mathrm{O}$ \\
5 & 20.30 & Phosphine, Triphenyl & $\mathrm{C}_{18} \mathrm{H}_{15} \mathrm{P}$ \\
6 & 21.66 & 1,6;3,4-Dianhydro-2-Deoxy-. beta.-d-Lyxo-Hexopyranose & $\mathrm{C}_{6} \mathrm{H}_{8} \mathrm{O}_{3}$ \\
7 & 22.50 & Paredrine TMS & $\mathrm{C}_{12} \mathrm{H}_{21} \mathrm{ONSi}$ \\
8 & 30.00 & Cyclotrisiloxane, Hexamethyl- & $\mathrm{C}_{6} \mathrm{H}_{18} \mathrm{O} \mathrm{Si}_{3}$ \\
\hline
\end{tabular}

Table 4: Chemical composition of Spermadictyon suaveolens leaves (chloroform extract)

\begin{tabular}{llll}
\hline Peak & RT & Peak name & Chemical formula \\
\hline 1. & 2.65 & Cyclobutanol & $\mathrm{C}_{4} \mathrm{H}_{8} \mathrm{O}$ \\
2 & 11.92 & 4-acetoxy-3-methoxy styrene & $\mathrm{C}_{6} \mathrm{H}_{18} \mathrm{O}_{3} \mathrm{Si}_{3}$ \\
3 & 12.71 & Cyclohexane, Decyl- & $\mathrm{C}_{16} \mathrm{H}_{32}$ \\
4 & 14.41 & 1-Pentadecene & $\mathrm{C}_{15} \mathrm{H}_{30}$ \\
5 & 14.74 & Palmitaldehyde, Di iso penty lacetal & $\mathrm{C}_{26} \mathrm{H}_{54} \mathrm{O}_{2}$ \\
6 & 15.34 & Benzene ethanamine, 3,4-benzyloxy-2,5-difluoro-. beta.-hydroxy-n-me & $\mathrm{C}_{23} \mathrm{H}_{23} \mathrm{O}_{3}$ \\
7 & 16.65 & 1-octadecene & $\mathrm{C}_{18} \mathrm{H}_{36}$ \\
8 & 17.51 & ethanone, 1-(3-methylene cyclo pentyl)- & $\mathrm{C}_{8} \mathrm{H}_{12} \mathrm{O}$ \\
\hline
\end{tabular}




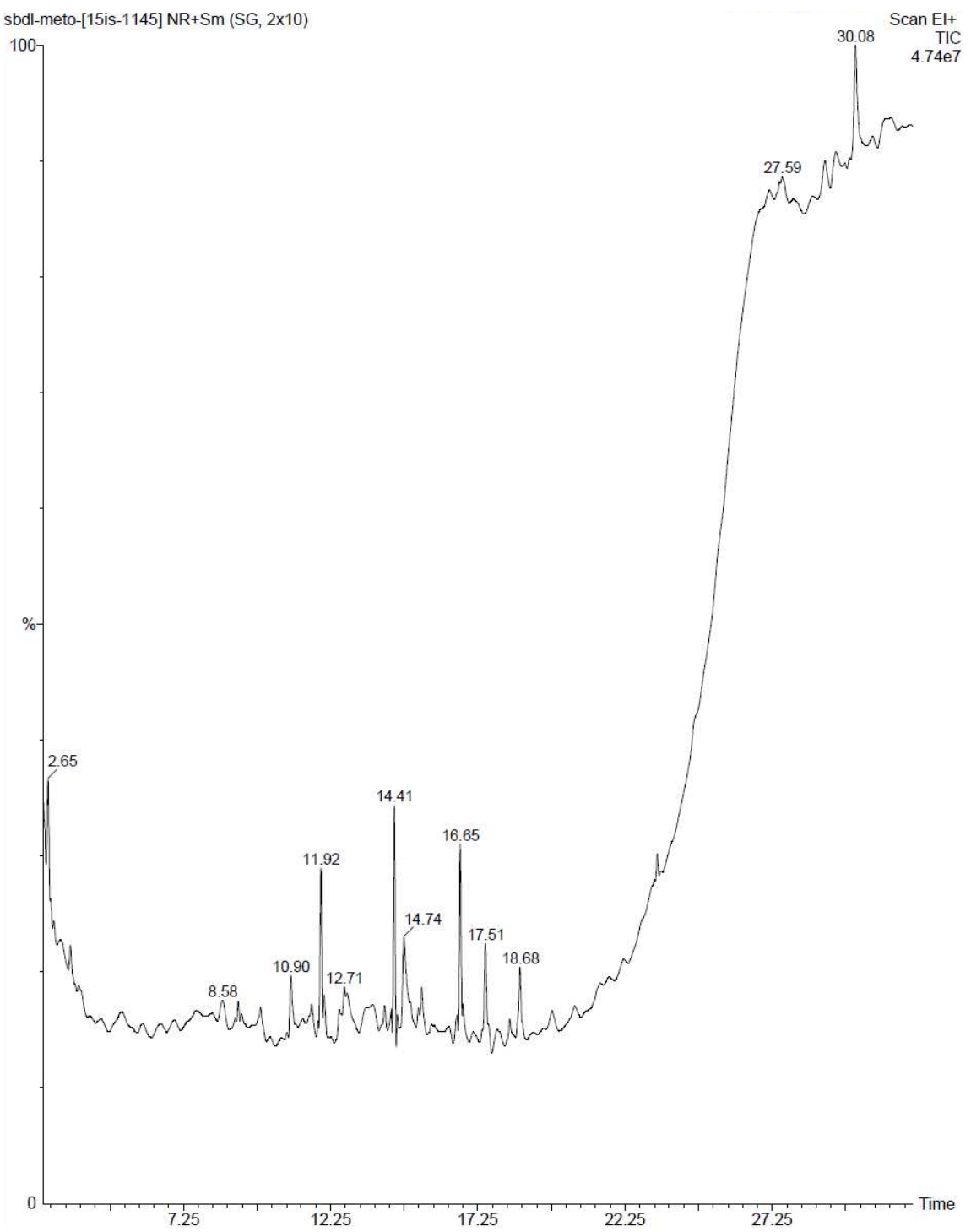

Fig. 7: GC-MS chromatogram of methanolic leaf extract of S. suaveolens leaf

Table 5: Chemical composition of Spermadictyon suaveolens leaves (methanolic extract)

\begin{tabular}{llll}
\hline Peak & RT & Peak name & Chemical formula \\
\hline 1. & 13.41 & Phenol, 2,4-bis(1,1-Dimethylethyl) & $\mathrm{C}_{14} \mathrm{H}_{22} \mathrm{O}$ \\
2 & 16.63 & e-14-Hexadecenal & $\mathrm{C}_{20} \mathrm{H}_{40} \mathrm{O}$ \\
3 & 17.08 & $3,7,11,15$-Tetramethyl-2-Hexadecen-1-ol & $\mathrm{C}_{16} \mathrm{H}_{30} \mathrm{O}$ \\
4 & 19.75 & Phytol & $\mathrm{C}_{20} \mathrm{H}_{40} \mathrm{O}$ \\
5 & 20.50 & Penta triacontene & $\mathrm{C}_{35} \mathrm{H}_{70}$ \\
6 & 22.20 & Bacteriochlorophyll-c-stearyl N4Mg & $\mathrm{C}_{52} \mathrm{H}_{72} \mathrm{O}_{4}$ \\
7 & 22.74 & Eicosane,9-octyl- & $\mathrm{C}_{28} \mathrm{H}_{58}$ \\
8 & 23.79 & Cyclotrisiloxane, Hexamethyl- & $\mathrm{C}_{6} \mathrm{H}_{18} \mathrm{O}_{3}$ \\
9 & 25.72 & Trimethyl[4-(1,1,3,3,-Tetra methylbutyl)phenoxy] Silane & $\mathrm{C}_{28} \mathrm{H}_{5}$ \\
10 & 25.97 & Octadecane, 3-ethyl-5-(2-ethylbutyl) & $\mathrm{C}_{17} \mathrm{H}_{30}$ \\
\hline
\end{tabular}

\section{CONCLUSION}

The present study was carried out to analyze of the presence of phytocompounds present in the unexplored plant Spermadictyon suaveolens, which belongs to the family Rubiaceae. UV-visible spectrophotometer analysis revealed absorption of the spectrum of known compounds. FT-IR analysis of functional groups of phytocompounds was analyzed with major peak values.

The individual phytochemicals present in the crude extract are identified by GC-MS. Since Spermadictyon suaveolens is found to have significant numbers of bioactive compounds based on GC-MS analysis; the compounds were found to have biological significance for treating various ailments as per earlier literature. Nevertheless, Isolation of unique phytocompounds from this plant and in-depth study of their biological activity will ensure best possible results in future and open new opportunity for discovery of potential drugs of therapeutic worth from this plant.

\section{ABBREVIATION}

GC-MS: Gas column-mass spectrophotometer; FTIR: Fourier transform infrared spectrometer; Ultraviolet-visible spectrophotometer; R. Tretention time. 


\section{CONFLICT OF INTERESTS}

Author's reveal no conflict of interest

\section{REFERENCES}

1. Vijyalakshmi R, Ravindran R. Preliminary comparative phytochemical screening of root extracts of Diospyros ferrea (Wild.) Bakh and Arvalanata (L.)Juss. Ex Schultes. Asian J Plant Sci Res 2012;2:581-7.

2. Gupta MK, Shrivastava AK, Singh AP, Chauhan, Gaur DS, Mishra $\mathrm{KK}$, et al. Comparative study of the shiva guggulu and simhanada guggulu in the management of amavata (rheumatoid arthritis). Int J Appl Pharm 2016;2:5-12.

3. Mahato SB, Sen S. Analysis of oil composition of the methanol extract of Coriandrum sativum Linn fruit by soxhlation technique. Int J Curr Pharm Res 2014;4:53-4.

4. Herouart D. Variations in the leaf alkaloid content of androgenic diploid plants of Datura innoxia. Planta Medica 1988;54:14-7.

5. Singh NP, Karthikeyan S. Flora of Maharashtra State Dicotyledon. Vol. 1. Flora of India. Series-2." Botanical Survey of India, Calcutta; 2000. p. 783.

6. Singh P, Ali SJ. Ethnomedicinal plants of family rubiaceae of Eastern UP. Indian J Life Sci 2012;1:83-6.

7. Patil D. Ethnobotany of Buldhana district (Maharashtra: India): Plants used in veterinary medicine. J Phytol 2011;2:22-34.

8. Kavita M, Rakshe A, Mokat D. Pharmacognostic studies of drug spermadictyon suaveolens roxb. Int J Pharm 2016;3:234-9.

9. Gaur R. Flora of the district Garhwal, North-West Himalaya (with ethnobotanical notes) Srinagar: Transmedia xii, 811p. ISBN 8190080733 En Anatomy and morphology Keys. Geog; 1999. p. 6.

10. Jackman R, Smith J. Anthocyanins and betalains, in Natural food colorants; 1996. p. 244-309.

11. Rice-Evans C, Miller N. Antioxidant activities of flavonoids as bioactive components of food. Biochem Soc Trans 1996;24:790-5.

12. Poiyamozhi A, Sundaraganesan N, Karabacak M, Tanrıverdi O, Kurt M. The spectroscopic (FTIR, FT-Raman, UV and NMR), first-order hyperpolarizability and HOMO-LUMO analysis of 4amino-5-chloro-2-methoxybenzoic acid. J Mol Struc 2012;1024:1-12.

13. Coates J. Interpretation of infrared spectra, a practical approach. Encyl of Anal Chem; 2000. p. 1-23.

14. Tsunoda A. Antiviral activity of alpha-methyl-1-adamantanemethylamine hydrochloride. Anti-Micro Agents C 1965;5:553.

15. Zhu ZZ. Analgesic, anti-inflammatory and antipyretic activities of the petroleum ether fraction from the ethanol extract of Desmodium podocarpum. J Ethnopharmacol 2011;133:1126-31.

16. Dangoggo S. Phytochemical analysis and antibacterial screening of leaves of Diospyrosme spiliformis and Ziziphusspina Christi. J Chem Eng 2012;1:57-62.
17. Silva RO. Phytol, a diterpene alcohol, inhibits the inflammatory response by reducing cytokine production and oxidative stress. Fund Clin Pharmacol 2014;28:455-64.

18. Padilla SS, Grizzle TB, Lyerly D. Triphenylphosphite: in vivo and in-vitro inhibition of rat neurotoxic esterase. Toxicol Appl Pharmacol 1987;87:249-6.

19. Al-Wathnani H. Bioactivity of natural compounds isolated from cyanobacteria and green algae against human pathogenic bacteria and yeast. J Med Plants Res 2012;6:3425-33.

20. Dahpour AA, Rahdari P, Sobati Z. The chemical composition of essential oil, antibacterial activity and brine shrimp lethality of ethanol extracts from Sedum pallidum. J Med Plants Res 2012;6:3105-9.

21. Govindappa M. Chemical composition of methanol extract of endophytic fungi, Alternaria sp. of Tebebuia argentea and their antimicrobial and antioxidant activity. Int J Life Sci Biotechnol Pharma Res 2014;5:861-9.

22. Sadananda T, Govindappa M, Ramachandra Y. In vitro antioxidant activity of lectin from different endophytic fungi of Viscum album L. Br J Pharm Res 2014;4:626.

23. Patil U, Deshmukh O. GC-MS Analysis of phytochemicals in the aqueous extract of Cyclea peltata.(Lam) Hook. $f$. and Thomson. Int J Sci Res 2016;4:350-1.

24. Abubacker MN, Palaniyappan KD. In vitro antifungal potentials of bioactive compounds heptadecane, 9-hexyl and ethyl isoallocholate isolated from Lepida gathiscristata Wild (Acanthaceae) leaf. Br Biomed Bull 2015;3:336-43.

25. Nakamura K, Hatakeyama T, Hatakeyama H. DSC Studies on hydrogen bonding of poly (4-hydroxy-3, 5-dimethoxystyrene) and related derivatives. Polym J 1986;18:219-25.

26. Igwe OU, Okwu DE. GC-MS Evaluation of bioactive compounds and antibacterial activity of the oil fraction from the seeds of Brachystegia eurycoma (HARMS). Asian J Plant Sci Res 2013;3:47-54.

27. Sathyaprabha G. A comparative study on antioxidant, proximate analysis, antimicrobial activity and phytochemical analysis of Aloe vera and Cissus quadrangularis by GC-MS. J Pharm Res 2010;3:2970-3.

28. Ertas A, Yilmaz MA, Firat M. Chemical profile by LC-MS/MS, GC/MS and antioxidant activities of the essential oils and crude extracts of two Euphorbia species. Nat Prod Res 2015;29:529-34.

29. Yinusa I, George NI, Ayo RG, Rufai Y. Evaluation of the pharmacological activities of beta-sitosterol isolated from the bark of Sarcocephalus latifolius (Smith Bruce). Globle J Pure Appl Chem Res 2015;3:7-14.

\section{How to cite this article}

- Ruthiran Papitha, Lokesh Ravi, Chinnadurai Immanuel Selvaraj. Phytochemical studies and GC-MS analysis of spermadictyon suaveolens roxb. Int J Pharm Pharm Sci 2017;9(3):143-149. 